\title{
STATE SUPPORT OF YOUTH ENTREPRENEURSHIP IN RUSSIA AND RUSSIAN REGIONS
}

\author{
E.A. Eremeeva ${ }^{1}$ \\ N.V. Volkova ${ }^{2}$ \\ T.V. Khalilova ${ }^{3}$
}

\begin{abstract}
The article is devoted to the analysis of support for youth entrepreneurship in Russia and Russian regions. Consideration of this topic is relevant, since, on the one hand, the interest of Russian youth in creating a business is growing, and on the other, society and the state are interested in young, initiative entrepreneurs. The article reviews, analyzes and compares the state support for young businessmen at the federal and regional levels. The main research methods are comparative analysis, analysis of regulatory legal acts of Russia and regions of the Russian Federation, systematization and generalization of legal information. The result of the study was the conclusion on the implementation of support for young entrepreneurs in the Russian Federation
\end{abstract}

and its feasibility. The main problems of this direction of support were highlighted. So, some discrepancies in federal and regional legislation, inaccuracies in the organization of the assistance process itself, the lack of a clear plan of measures to support this type of business, etc. were revealed. Recommendations were also proposed that will help to overcome these problems and make the support of young entrepreneurs more accessible, appropriate and effective. So, for example, it was proposed to simplify the very concept of youth entrepreneurship, to fix at the federal level the main directions of its support, etc.

Keywords: youth, business, region, support, youth entrepreneurship.

\footnotetext{
${ }^{1}$ Kazan Federal Univercity, Institute of Management, Economics and Finance, Kazan, 420008, Russia. 896005771 46. Email: anka_2007_901@mail.ru.

${ }^{2}$ Kazan Federal Univercity, Institute of Management, Economics and Finance, Kazan, 420008, Russia. 896005771 46. Email: anka_2007_901@mail.ru.

${ }^{3}$ Kazan Federal Univercity, Institute of Management, Economics and Finance, Kazan, 420008, Russia. 896005771 46. Email: anka_2007_901@mail.ru.
} 


\section{Introduction.}

Youth is one of the key foundations of a future state. It forms human capital for the future economy. The demographic situation in the country depends on young people. Youth is becoming a source of new ideas and achievements. An important place among young people is occupied by young entrepreneurs. They create new jobs, develop competition, contribute their innovations and ideas. In general, they become the basis for the development of the state economy.

According to a survey by Career.ru in 2018, a third of young professionals in the Russian Federation expressed a desire to start a business [1]. That is, the interest of Russian youth in creating their own business is great. It should be noted that youth entrepreneurship is associated with great risk. The young businessman does not yet have experience in his field. He has no business connections and business partners. The young entrepreneur has extremely limited starting financial opportunities due to the lack of savings.

Such a contradictory nature of the youth business makes its state support relevant. The state, on the one hand, should motivate young people to open their own business and create conditions for this. On the other hand, authorities should support young businessmen and help them overcome difficulties. In this regard, the study of state support for youth entrepreneurship is relevant at the moment.

The relevance of this topic is confirmed by the scientific interest in it of other scientists. A number of studies analyze the importance of youth entrepreneurship for economic development and overcoming the problem of unemployment in the state $[2$, $3]$. One of the most relevant aspects of this topic can be considered the issue of motivation and intentions of young people to do business. A number of works are devoted to identifying the main factors affecting young people and their desire to do business [4]. Some works deal with individual factors that influence the intentions of young people. Many scientists study a factor such as education. The influence of secondary school educational programs $[5,6]$, professional education programs at universities $[7,8]$ on the desire of young people to do business is studied. In 
addition to education, factors such as the social status of youth [9], the economic and historical situation in the state [10], social and cultural differences of territories [11], etc. are also studied. State policy with regard to youth and business does not go unnoticed. A number of studies demonstrate the positive experience of state support for entrepreneurship. So, Cavada, M.C., Bobek, V., Maček, A. describe the positive experience of state support for women's entrepreneurship in Mexico. Young girls are greatly assisted by a specialized state program to support women's business [12]. A number of studies examine the negative experiences of government support for youth and youth entrepreneurship. Thus, Madichie, N.O., Mpiti, N., Rambe, P. conclude that state financial assistance to young entrepreneurs in the South African Republic leads only to an increase in debts, but not to business promotion [13]. Arlow, J., in his study examines the national internship system in Ireland, JobBridge, and concludes that this system seriously infringes on the rights of unemployed youth whose work is free of charge [14]. That is, we can say that state support for youth entrepreneurship in different countries is organized in different ways and can have not only positive, but also negative consequences. Our task is to study how support for young entrepreneurs is organized in Russia and whether it is appropriate.

\section{Research Method.}

The study of state support for youth entrepreneurship in the Russian Federation included several stages. The logic and progress of the study was determined by the fact that in Russia state support for youth entrepreneurship has a complex organization. Firstly, this support combines two areas of work at once: business support and youth support. Secondly, the support of young entrepreneurs involves the joint work of both federal and regional governments. In this regard, this study examines two areas of public policy at two levels of government. This made it possible to more fully analyze state support for youth entrepreneurship in the Russian Federation and determine its further development.

At the first stage, an analysis of the regulatory legal acts of the Russian Federation on youth and business 
support was carried out. This made it possible to identify the main areas of support for youth entrepreneurship.

At the second stage, an analysis of regulatory acts at the level of regions of the Russian Federation was carried out. Several regions were selected for analysis: the Republic of Bashkortostan, the Republic of Mari El, the Republic of Mordovia, the Republic of Tatarstan, the Republic of Udmurtia, the Chuvash Republic.

The experience of the regions is considered in two directions: business support and youth support. In each of these areas, a comparative analysis of the regions was carried out according to the following criteria:

- the presence of a specialized state body or organization that provides support;

- the existence of a specialized law that enshrines the foundations of the considered policy area;

$$
\text { - consolidation }
$$

provisions on youth entrepreneurship and its support in this law;

- availability of a strategy / program in this policy area;

$$
\text { - consolidation of }
$$

provisions on supporting young businessmen in this strategy / program.

The generalization and comparison of information on each of the criteria allowed us to compare the regions with each other and determine how the system of state support for youth entrepreneurship in Russia and its regions is organized.

\section{Results}

The analysis of federal legal acts in relation to business and youth led to the following conclusions.

Support issues for youth entrepreneurship are related to youth policy. However, this policy area at the federal level is still underdeveloped. This is evidenced by the following facts. Firstly, while at the federal level there is no specialized law that would enshrine the basic principles and directions of youth support, including youth entrepreneurship. Secondly, the organization of authorities responsible for youth support is changing quite often. The body that is responsible for implementing youth policy has been transformed and changed its status more than 7 times since 1992. 
At the same time, youth policy issues were combined with other areas of politics: in the field of labor, education and science, sports and tourism. Currently, the Federal Agency for Youth Affairs of the Russian Federation is responsible for the implementation of youth policy. It is independent and reports directly to the Government of the Russian Federation [15].

The main document of youth policy at the moment is the Fundamentals of State Youth Policy until 2025 [16]. This document contains two important aspects of youth entrepreneurship:

1. The very definition and status of youth entrepreneurship;

2. the need to support young entrepreneurs;

Regarding the very concept of "youth entrepreneurship" we can say the following. Firstly, it seems impractical to fix this term in this document. The specified document is valid until 2025. After that, it will cease to act, that is, the very definition of "youth entrepreneurship" will cease to operate. Secondly, the definition indicates signs of youth entrepreneurship:
326

- $\quad$ age of the owner (up to 30

years);

- company size (small or medium business);

- age requirements for employees and the head (the average age of employees and the director should not exceed 30 years);

- age requirements for the participants (owners) of the company and their share in the authorized capital (at least $75 \%$ of the authorized capital should be held by participants under 30 years old).

Some of these requirements may be considered inappropriate. So, in our opinion, it makes no sense to limit the size of the company or establish a requirement for employees. We believe that it is necessary to make demands only on the entrepreneurs themselves. It is assumed that youth entrepreneurship is the type of business that will focus on creating a new product and introducing new ideas. And it depends on the decision directly of the owners - young entrepreneurs. Therefore, you need to make demands only on them.

In addition, such a proposal will simplify the classification and separation 
of youth entrepreneurship from the total number of companies.

On the support of youth entrepreneurship in the Fundamentals of Youth Policy, only the fact of support is indicated. There are no clarifications on the types and directions of support in the document.

That is, we can say that at the federal level only the status of youth entrepreneurship is established. Accordingly, it can be assumed that the directions and support measures are enshrined in regional acts.

The analysis of regional acts [17] was also carried out in two directions. First, we present the results of the analysis of information on regional youth policy. They are shown in the Table 1.

Table 1.

Implementation of youth policy and support for youth entrepreneurship in the regions of the Russian Federation

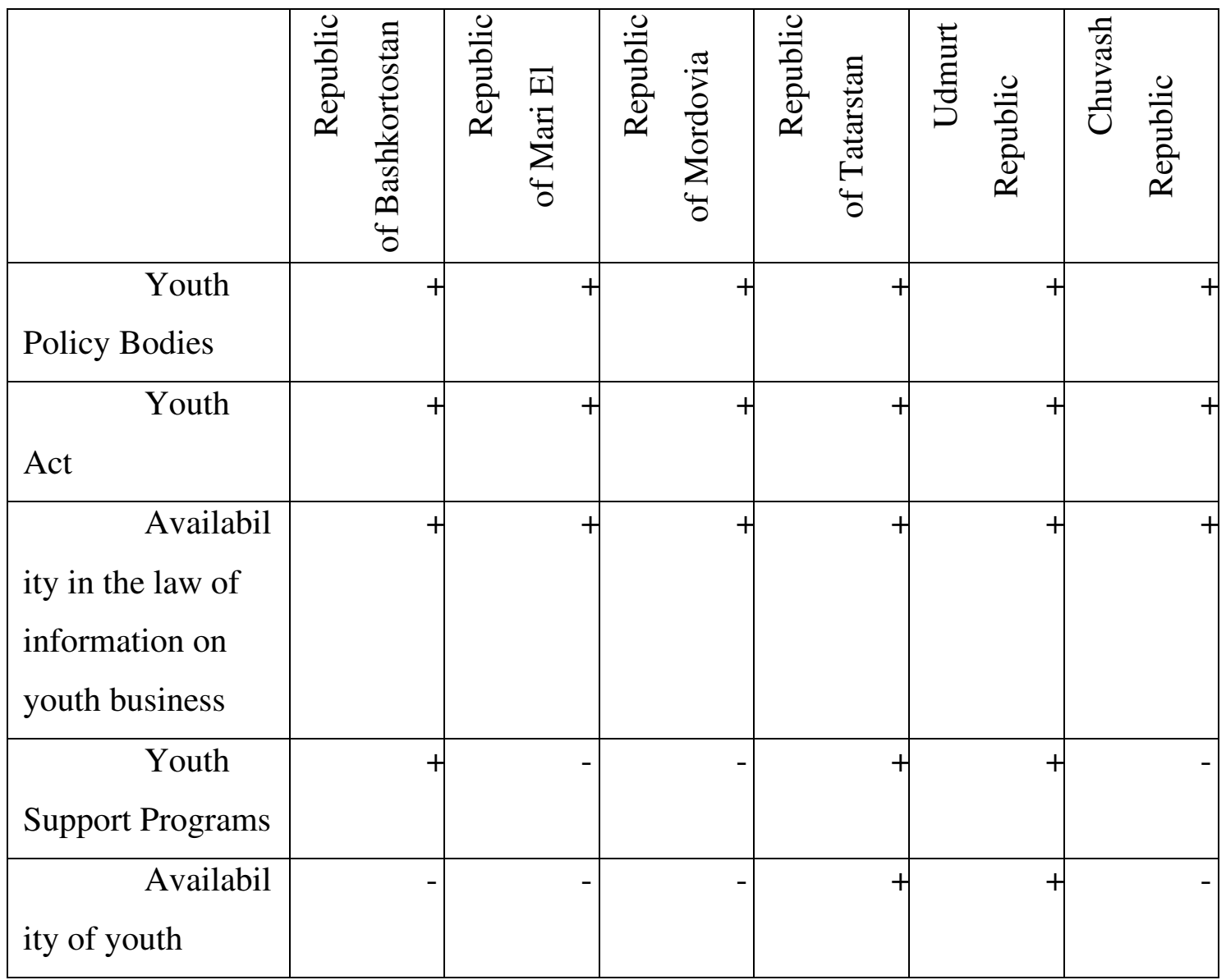




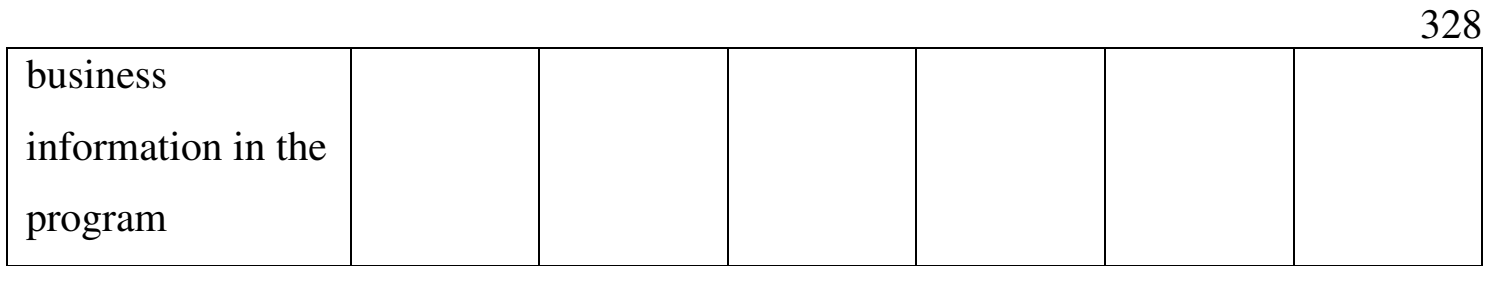

From the Table 1 we can draw the following conclusions. At the regional level, youth policy is recognized. This is evidenced by the presence of relevant bodies and laws on youth. The absence of youth policy programs in some regions suggests that youth policy is either just being declared but not being implemented. Or it is realized, but chaotically and uncontrollably.

$$
\text { Regarding youth }
$$
entrepreneurship, we can say that its support is enshrined in all regions (in regional laws). Some laws on youth enshrined the concept of youth entrepreneurship (the law of the republics of Bashkortostan, Udmurtia, Chuvashia). However, none of them meets the definition at the federal level. A number of laws (Mari El Republics, Chuvashia, Udmurtia) indicate the areas of support: information, legal, organizational support. A number of laws (Republics of Mordovia, Chuvashia) specify support measures: tax incentives, subsidies, etc. However, when considering programs on youth policy, which should contain a specific plan for the implementation of these areas and measures, the following was established. Only in the programs of the two regions are individual measures indicated. In Tatarstan, only support for young entrepreneurs in rural areas is provided. In Udmurtia, only two support measures are provided (although much more is listed in the law of the Republic).

Thus, we can say that, in the framework of youth policy, support for youth entrepreneurship, although it is provided, is not implemented.

Next, we present the results of the analysis of information on business support in the regions (see the Table 2).

Table 2.

Implementation of business support, including young entrepreneurs, in the regions of the Russian Federation 


\begin{tabular}{|c|c|c|c|c|c|c|}
\hline & 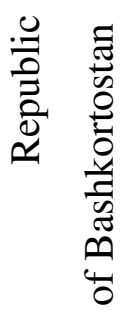 & 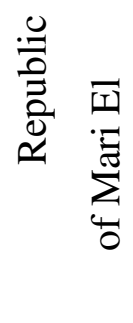 & 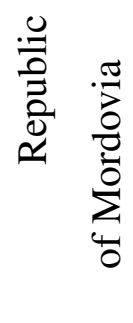 & 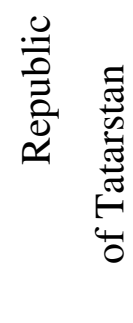 & 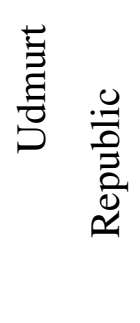 & 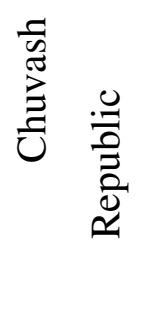 \\
\hline $\begin{array}{l}\text { Business } \\
\text { Support Bodies }\end{array}$ & & & & & & \\
\hline $\begin{array}{l}\text { Entrepreneu } \\
\text { rship Act }\end{array}$ & & & & & & \\
\hline $\begin{array}{l}\text { Availability } \\
\text { in the law of } \\
\text { information on youth } \\
\text { business }\end{array}$ & & & & & & \\
\hline $\begin{array}{r}\text { Business } \\
\text { Support Programs }\end{array}$ & & & & & & \\
\hline $\begin{array}{l}\text { Availability } \\
\text { of youth business } \\
\text { information in the } \\
\text { program }\end{array}$ & & & & & & \\
\hline
\end{tabular}

The information from table 2 indicates the following. The laws of the regions on business support do not provide for such a type of business as youth. Consequently, these laws do not provide support for this type of business. At the same time, this type of entrepreneurship already appears in business support programs. However, specific activities are provided only in the program of the Republic of

Chuvashia:
- holding contests and grants for young entrepreneurs;

- creation of information centers for young businessmen.

That is, we can say that the events aimed specifically at young businessmen in this direction of politics are not provided for in the same way as in youth policy programs.

\section{Discussion}


Thus, regarding the support of youth business in the Russian Federation and regions of the Russian Federation, the following can be noted. This type of business and its support are envisaged and consolidated, but there is no clear plan for supporting young businessmen at the regional or federal levels. At the regional level, support itself is declared and secured, but there is no clear indication of how it is provided. In addition, there is no clear idea of which body provides it. On the one hand, youth entrepreneurship is spelled out in the law on youth, which is carried out by the youth policy body. On the other hand, youth entrepreneurship is more often mentioned in business support programs that are already being implemented by other state bodies in the regions. It is also an obstacle in supporting young entrepreneurs.

\section{Conclusion}

To overcome the identified problems, the following is proposed:

- legislative consolidation at the federal level of the very concept of "youth entrepreneurship"; bringing into compliance with this all legal acts at the regional level;
330

- simplification of the definition of youth entrepreneurship: the following definition is proposed: "youth entrepreneurship is the entrepreneurial activity of citizens under 30 years of age or legal entities, at least $75 \%$ of the authorized capital of which is held by persons under 30 years of age"

- allocation of areas of support for young entrepreneurs at the federal level (information and advisory, administrative and legal, educational, financial and economic, infrastructural support);

- detailed development of an action plan within the framework of the indicated areas of support in regional youth support programs.

These measures, in our opinion, will allow not only to consolidate the support of youth entrepreneurship, but also to begin its implementation in practice.

\section{Acknowledgements}

The work is performed according to the Russian Government Program of Competitive Growth of Kazan Federal University.

\section{Bibliography}


The results of a survey of young professionals on important aspects of the choice of an employer at the beginning of a career [Electronic resource] // HeadHunter Group of Companies. Access mode: https://kazan.hh.ru/article/22996

(accessed June 30, 2019)

Teixeira, S. J., Casteleiro, C. M. L. Rodrigues, R. G., Guerra, M. D. Entrepreneurial intentions and entrepreneurship in European countries // International Journal of Innovation Science, Volume 10, Issue 1, 2018, Pages 22-42.

Moldazhanova, A.A., Dzhumazhanova, G.K., Amanova, A.K., Kokoraeva, A.K. Improving the mechanism of youth employment in the commonwealth of independent states in the global context // Journal of Entrepreneurship Education, Volume 22, Issue 1, February 2019.

Velásquez, J.A.T., Arias, A.V., Hernández, J.B., Díez-Echavarría, L.F., Marín, M.L.U., Pérez, F.O.M. Characterization of entrepreneurial intention in university students as from

\section{1}

Systemic Entrepreneurship Intention Model: A case study // Cuadernos de Gestion, Volume 18, Issue 2, 2018, Pages 95-114.

Blimpo, M.P., Pugatch, T. Entrepreneurship education and teacher training in Rwanda // Journal of Development Economics, Volume 140, September 2019, Pages 186-202.

Ševkušić, S., Stojanović, L., Simijonović, R. Which factors shape the intention of secondary school students in Serbia to pursue entrepreneurship? // Zbornik Instituta za Pedagoska Istrazivanja, Volume 50, Issue 1, 2018, Pages 158- 181.

Bharucha, J. Entrepreneurship education management in India // International Journal of Business Excellence, Volume 17, Issue 4, 2019, Pages 456-468.

Purwana, D., Suhud, U. Investigating the effect of motivation on entrepreneurial intention: Three different approaches // Problems and Perspectives in Management, Volume 16, Issue 2, 2018, Pages 200-208. 
Rantanen, T., Pawlak, A., Toikko, T. The significance of social welfare attitudes in young people's entrepreneurial intentions // Entrepreneurial Business and Economics Review, Volume 3, Issue 1, 2015, Pages 43-60.

Alegre, I., Berbegal-Mirabent, J. Entrepreneurship and the influence of history: How much impact do countryspecific historical factors have on entrepreneurship initiatives? // Entrepreneurship, Regional Development and Culture: An Institutional Perspective, January 1, 2015, Pages 35-52.

Gimenez, D., Peris-Ortiz, M., Urbano, D. A cultural perspective on entrepreneurship and regional development: The case of the bages (Catalonia) // Entrepreneurship, Regional Development and Culture: An Institutional Perspective, 1 January 2015, Pages 1-21.

Cavada, M.C., Bobek, V., Maček, A. Motivation factors for female entrepreneurship in Mexico // Entrepreneurial Business and Economics
Review, Volume 5, Issue 3, 2017, Pages 133-148.

Madichie, N.O., Mpiti, N., Rambe, P. Impact assessment of funding on technology acquisition by small businesses: A case study of hair salons in a South African municipality // Journal of Enterprising Communities Volume 13, Issue 1-2, May 31, 2019, Pages 145166.

Arlow, J. A JobBridge to nowhere: The National Internship Scheme as fast policy leading to bad policy // Administration, Volume 67, Issue 2, 1 May 2019, Pages 71-93.

Agency for Youth Affairs of the Russian Federation [Electronic resource]. Access Mode: https://fadm.gov.ru/agency/about (accessed June 30, 2019)

The order of the Government of the Russian Federation No. 2403-r dated 11.29.2014 "On the approval of the Fundamentals of state youth policy until 2025" [Electronic resource] // Government of the Russian Federation. Access mode: 
Periódico do Núcleo de Estudos e Pesquisas sobre Gênero e Direito

Centro de Ciências Jurídicas - Universidade Federal da Paraíba

V. 8 - N 06 - Ano 2019 - Special Edition

ISSN | 2179-7137 | http://periodicos.ufpb.br/ojs2/index.php/ged/index

http://government.ru/docs/15965/

(accessed June 30, 2019)

Regional legislation [Electronic

resource] // Electronic fund of legal and

regulatory and technical documentation

"Consortium Code". Access mode:

http://docs.cntd.ru/search/region

(accessed June 30, 2019) 